\title{
EKSPRESJA JAKO RODZAJ WERBALIZACJI I EKSPRESYWY WERBALNE W UJĘCIU ONOMAZJOLOGICZNYM
}

\author{
Piotr CZAJKOWSKI \\ doktorant Uniwersytetu Jana Kochanowskiego w Kielcach (POLSKA) \\ https://orcid.org/0000-0002-4628-8666
}

DOI 10.25128/2304-1222.20.50.08

\begin{abstract}
This article aims to determine the essence of expressing senses, emotional states, and volitional acts through exclamations as verbal expressions. Exclamations are present in all languages, but depending on the language and cultural region, they have a different scope, pragmatics of use. Thus, their description in the literature may vary. Onomasiology, as a linguistic discipline, deals with the representation of mental acts and a linguistic picture of the world in the language. The representation achieved, primarily through verbalization of ideas in nominative acts. The research in non-conceptual verbalizations of a linguistic picture of the world (emotional states, volitional acts, and sensual representations) still does not provide us with a clear answer about their semiotic origine. The problem of the typology of lexical units which verbalize functions of mental representations remains unclear. The author suggests highlighting the semantic expression along with primary ways of verbalization (i.e., nomination and predication) as a demonstrative procedure in speech and the non-conceptual language.
\end{abstract}

Keywords: onomasiology, expression, nomination, predication, exclamations, verbal expressions, verbal demonstration.

Метою статті є спроба встановити суть вираження чуттєвих образів, емоціональних станів і вольових актів за допомогою вигуків як вербальних експресивів. Вигуки наявні в усіх мовах, але в залежності від мовно-культурної сфкри вони мають різний обсяг, прагматику вжитку і по-різному описуються в літературі. Ономасіологія як лінгвістична дисципліна займається відображенням в мові і мовленні картини світу і психічно-ментальних актів насамперед через вербалізацію понять в актах номінації. Дослідження в аспекті вербалізації непоняттєвих функцій картини світу (емоційних станів, вольових актів і чуттєвого сприйняття) надалі не дають чіткої відповіді про їх семіотичну сутність, а проблеми типології лексичних одиниць, що вербалізують функції такого роду, залишаються не до кінця з'ясованими. Автор пропонує поряд з основними способами вербалізації - номінацією і предикацією - також вирізняти семантичну експресію як процедуру демонстрації у мові та мовленні непоняттєвої шнформації.

Ключові слова: ономасіологія, експресія, номінація, предикація, вигук, вербальні експресиви, вербальна демонстрація.

Celem artykułu jest próba ustalenia istoty wyrażenia wyobrażeń zmysłowych, stanów emocjonalnych i aktów wolitywnych za pomocą wykrzyknień jako ekspresywów werbalnych. Wykrzyknienia są obecne we wszystkich językach, ale w zależności od obszaru kulturowo-językowego mają różny zakres i pragmatykę użycia i są różnie opisywane w literaturze przedmiotu. Onomazjologia jako dyscyplina lingwistyczna zajmuje się odzwierciedleniem w języku i mowie obrazu świata oraz aktów umysłowo-psychicznych przede wszystkim poprzez werbalizację pojęć w aktach nominacji. Badania w aspekcie werbalizacji niepojęciowych funkcji obrazu świata (stanów emocjonalnych, aktów woli i wyobrażeń zmysłowych) nadal nie dają jasnej odpowiedzi odnośnie ich istoty semiotycznej, a problem typologizacji jednostek leksykalnych werbalizujących takiego rodzaju funkcje pozostaje nie do końca wyjaśniony. Autor proponuje obok podstawowych sposobów werbalizacji - nominacji i predykacji - wyróżniać również ekspresję semantyczną jako procedurę demonstracji w mowie oraz języku treści niepojęciowych. 
Słowa kluczowe: onomazjologia, ekspresja, nominacja, predykacja, wykrzyknik, ekspresywy werbalne, demonstracja werbalna.

Badanie onomazjologiczne ma charakter wybitnie antropocentryczny i relacjonistyczny (funkcjonalny i pragmatyczny). U jej podstaw leży rozumienie każdego zjawiska językowego lub mownego jako funkcji (patrz О. Лещак 2000) oraz wartości (Leszczak 2002) doświadczenia ludzkiego. Natomiast samo badanie onomazjologiczne polega na pojmowaniu każdego znaku językowego jako wyniku procesu werbalizacji pewnych treści pozajęzykowych. Onomazjologiczny sposób rozpatrywania zjawisk językowych zakłada, że nadrzędny punkt widzenia to punkt widzenia nadawcy, zakładający cel przełożenia pewnych treści pozajęzykowych na formę językową, wybierając ją z dostępnego zasobu językowego, i przekształcenie ich zgodnie z regułami językowymi w treści mowne. Badanie aktów werbalizacji, przede wszystkim aktów nominacji pozwala nam wyciągnąć wniosek na temat tego, jak rzeczywistość pozajęzykowa jest rozparcelowana przez nasz umysł, jakie są motywy aktów werbalizacyjnych i jakie kategorie onomazjologiczne znajdują odzwierciedlenie na poziomie słowotwórczym, gramatycznym i leksykalnym. Kategoria onomazjologiczna zwykle jest kategorią nominatywną, która tworzy specjalne pola nazw pojęć w języku. Nie ma wątpliwości, że istnieje związek między ludzką aktywnością poznawczą, kategoriami pojęciowymi i kategoriami onomazjologicznymi. Jest to bowiem podstawowa zasada wyrażania takich struktur onomazjologicznych za pomocą znaków językowych (Dokulil 1979: 44).

Jako teoria nominacji, onomazjologia zawsze stała w opozycji do semazjologii (teorii opisu znaczeń jednostek językowych). Jej głównym obiektem badania jest proces nominacji, czyli nazywania i wyrażania za pomocą jednostek językowych pewnych treści kognitywnych (pojęć, wyobrażeń a niekiedy również sądów). Nominacja stanowi nie tylko proces porządkowania rzeczywistości, ale także sposób jej interpretacji. Wynika z potrzeby nazewnictwa, tj. posiadania znaku oznaczającego ten lub inny fragment obrazu świata. Można powiedzieć, że jest to wieloetapowy akt wyodrębnienia i „ujednostkowienia” tego fragmentu w języku. (Rejter 2009: 236). Nominacja jest zawsze poprzedzana motywacją, której istotą jest poszukiwanie usprawiedliwienia do takiego a nie innego nazywania danego zjawiska. Zjawisko motywacji ma charakter zarówno semantyczny jak i pragmatyczny, gdyż osoba dokonująca nominacji robi to w pewnym celu, który często jest związany z typem działalności lub sytuacją językową. Zdaniem Artura Rejtara „,nominacja ma naturę kompleksową, w której nie tylko czynnik psychologiczny i semantyczny, ale też pragmatyczny odgrywa znaczącą rolę" (tamże: 236).

Pojęcie motywacji jest również bezpośrednio związane $\mathrm{z}$ formalną stroną nominatu jako produktu nominacji, gdyż w ten lub inny sposób wskazuje na jednostkę lub jednostki motywujące daną nazwę co jest wyrażane w tzw. ,wewnętrznej formie słowa”. Wewnętrzna forma słowa jako 
znaczenie motywacyjne może stanowić część składową leksykalnego znaczenia słowa. Od strony formalnej wszystkie nominaty dzielą się na prymarne i pochodne.

Za pochodne uważane są takie nominaty, których forma może być objaśniona i wyprowadzona $\mathrm{z}$ form motywujących ją jednostek. Jeżeli takiej procedury $\mathrm{w}$ badaniu funkcjonalnym dokonać się nie da, to forma taka jest uważana za prymarną.

Jeśli mówimy o nominacji jako akcie nadawania językowej nazwy, to taka procedura może mieć trzy odsłony: pierwotną, powtórną i wtórną. Pierwotna nominacja to nazywanie pewnego obiektu po raz pierwszy, a pierwotny nominat to nazwa, która jest uważana za główną i powszechnie przyjętą dla tego obiektu. Czasem powstaje dyskursywna potrzeba renominacji, czyli powtórnego nazywania tegoż obiektu w jakimś pragmatycznym lub stylistycznym celu (np. uproszczenia lub doprecyzowania). Tego typu zabiegi nazywamy powtórną nominacją, a powstałe w ich wyniku jednostki powtórnymi nominatami. Tak np. Rzeczpospolita Polska, Rzeczpospolita oraz $R P$ są powtórnymi nominatami w stosunku do pierwotnego nominatu Polska. Natomiast w szeregu przypadków powstaje potrzeba estetycznego udziwnienia albo alegorycznego nazywania danego obiektu, które najczęściej nie ma nic wspólnego z jego pierwotną lub powtórną nazwą, np. Ciemnogród, Klechistan, Katoland lub Ubekistan, którymi to nazwami w publicystyce mianują Polskę. Są to przykłady wtórnej nominacji.

Nominacja, której wynikiem jest nominat językowy (słowo, frazem, frazeologizm), wiąże się przede wszystkim z nazywaniem pojęć. Kognitywną podstawą predykacji natomiast jest sąd jako relacja pojęć przedstawiająca informację jako wydarzenie komunikatywne. W wyniku predykacji powstają wypowiedzi, przede wszystkim zdania i teksty. Niektórzy naukowcy obok tych dwóch procedur werbalizacyjnych wyróżniają również tzw. półpredykację. Przy półpredykacji dochodzi jednocześnie do obu procedur - nominacji pewnego fragmentu obrazu świata (nominacji) oraz przedstawienia tego fragmentu w jego aktualizowanych relacjach do innych elementów myślenia. Zatem obiektami półpredykacji mogą być aktualizowane pojęcie albo relacje między pojęciami jako część sądu, a werbalnym wynikiem jej są luźne połączenia wyrazowe albo aktualizowane w mowie wyrazy. Są to najczęściej różnego rodzaju zwroty, porównania, apostrofy czy figury retoryczne.

Oprócz trzech opisanych wyżej procedur werbalizacyjnych można wyróżnić jeszcze jeden typ werbalizacji informacji psychicznej, który nie do końca mieści się w wytyczonych przez nie granicach. Chodzi o ekspresję werbalną jako demonstrację informacji pozapojęciowych. Ma ona miejsce wtedy, gdy mamy do czynienia $\mathrm{z}$ jednostkami przedmyślowymi tj. ogólnymi wyobrażeniami o stanach emocjonalnych, aktach woli czy sensorycznych przeżyciach, które nie mogą być nazwane, ponieważ nie są pojęciami, ale również nie zawsze mogą być przedstawione jako propozycja, gdyż jako wyobrażenia same z siebie nie są sądami. Takie jednostki nazywają wykrzyknieniami, wykrzyknikami, imteriekcjami, onomatopeja, predykatywami ekspresywnymi, 
semileksemami etc. Proponujemy je nazywać ekspresywami werbalnymi ze względu na ich zasadniczą istotę semiotyczno-pragmatyczną. Problem uchwycenia tego typu jednostek jako obiektów badania lingwistycznego może polegać na tym, że są to jednocześnie jednostki leksykalne (jednostki zasobu znaków leksykalnych), ale przy tym o wiele bardziej niż wszystkie inne leksemy uzależnione od sytuacji mownej i werbalizujące jakościowo odmienny typ zjawisk psychoinformacyjnych. Pytanie brzmi: któremu działowi językoznawstwa - leksykologii czy składni - podlegają tego rodzaju znaki? Trudno się nie zgodzić z A. Rogalą, że „większość istniejących typologii emotywnych środków języka albo odnosi się jedynie do nacechowanych emocjonalnie leksemów i wyrażeń, albo opiera się w głównej mierze na kryterium składniowym" (Rogala 2019: 197). Dotyczy to również innych funkcji lingwosemiotycznych werbalizujących nie pojęciowe informacje - wolitywnych i sensorycznych.

Składnia zajmuje się procesami tworzenia aktów mowy (wypowiedzi, jedności ponadfrazowych i tekstów) na podstawie modeli syntaktycznych oraz z wykorzystaniem szeroko pojętego zasobu leksykalnego. Jest nastawiona wyraźnie na aktualne (występujące tu i teraz) sytuacje mowne. Leksykologia zaś jest przede wszystkim dziedziną opisu inwariantnego zasobu znaków systemu językowego. Często sprowadzają ją do opisu słownictwa, czyli zasobu słów jako nominatywnych znaków pewnych pojęć (stąd próby wydzielenia w osobne dyscypliny frazeologii $\mathrm{i}$ frazematyki). W lingwistyce funkcjonalno-pragmatycznej obiektem badania są nie tyle środki i produkty działalności językowej, ile same procesy tej działalności wraz z ich motywacjami i celowymi nastawieniami. Zatem dziedziną, która zajmuje się zarówno tworzeniem zasobu leksykalnego (albo szerzej - zasobu informacyjnej bazy języka), jak i zapewnieniem procesów lingwosemiotycznych w trakcie działalności mownej, jest onomazjologia. Przy tym interesuje ją nie tylko świadome intencjonalne tworzenie aktów mowy, ale także nieuświadamiane lub niekontrolowane działania i procesy werbalizacyjno-interpretacyjne.

Karl Buhler swego czasu zróżnicował działania językowe oraz akty mowy na zasadzie stopnia uświadomienia zabiegu werbalizacyjnego $\mathrm{i}$ zaangażowania $\mathrm{w}$ ten proces systemu językowego. Pierwsze mają charakter subiektywny i są minimalnie sformalizowane. Zdaniem J. Antas i M. Majewskiej, owe działanie językowe ,jest zatem raczej ekspresją myśli i emocji niż ich świadomym wyrazem. Dopiero «akt językowy» (...) jest działaniem komunikacyjnie świadomym - mówiący dokonuje wyboru formy lub formuły językowej, która (...) wyraża określane potrzeby wypowiedzenia się" (Antas, Majewska 2019: 14). W tej interpretacji poglądów Buhlera jest pewien problem. Ponieważ większość jednostek (w tym wyrażających stany psychiczne), które są wykorzystywane w mowie, należy do zasobu językowego, zatem są one inwariantne i odtwarzalne, czyli w myśl Buhlera, powinna być obiektem „wyboru formy lub formuły językowej” oraz wyrażać „określane potrzeby wypowiedzenia się”. A to znaczy, że żadna jednostka języka nie służy „ekspresji myśli i emocji” (w sensie wyrażonym w cytacie) i każdy tzw. 
„akt mowy” powinien być świadomym wyrazem myśli i emocji. Obie te kwestie są dość wątpliwe, gdyż dość często nawet wypowiadane sądy zawierające nominacje pojęć (słowa i frazemy) są przez mówce nie uświadamiane. Trudno też uważać wypowiedzenie jakiegoś wykrzyknienia jako reakcji na gwałtowną zmianę stanu psychicznego za akt w pełni uświadamiany. Zatem do tego, co Buhler nazywa „działaniem językowym” w takim układzie można odnieść wyłącznie jednostki okazjonalne, które powstają ad hoc, nie utrwalają się w zasobie językowym i znikają tuż po ich wypowiedzeniu. Nas zaś w tej kwestii interesują raczej utrwalone w zasobie leksykalnym inwariantne jednostki językowe, których oznaczanym nie są pojęcia o wrażeniach i uczuciach, a jedynie wyobrażenia o nich, co plasuje je pomiędzy klasycznymi pełnowartościowymi znakami leksykalnymi (wykorzystywanymi w aktach mowy) a ww. okazjonalizmami (funkcjonującymi w działaniach językowych). Jednakże teoretycznie można się zgodzić z postawą Antas i Majewskiej, jeśli przyjąć, że kwestia świadomości komunikacyjnej w zaproponowanym zróżnicowaniu działań językowych i aktów mowy zostanie zastąpiona pojęciowym lub niepojęciowym charakterem werbalizowanych treści, tym bardziej że same autorki trochę niżej przyznają, iż „trudno wyznaczyć ostre granice między świadomym i nieświadomym działaniem mownym, a tym bardziej wyznaczyć czyste granice jego formalizacji” (tamże). Uświadamianie jest aktem refleksji i nie koniecznie musi dotyczyć pojęć czy sądów. Można wiedzieć coś (posiadać wiedzę pojęciową) i nie uświadamiać tego, można również posiadać jedynie odczucia, uczucia i wyobrażenia ogólne (nie wiedząc, co to jest) i uświadamiać sobie tę informację niepojęciową W momencie reakcji na coś, co nas wystraszyło, zdajemy sobie sprawę, w jakim stanie jesteśmy i reagujemy standardowo - używając wykrzyknienia, które zazwyczaj jest w takich sytuacjach wykorzystywane przez innych przedstawicieli naszej kultury językowej, jednak nie koniecznie w tym momencie (albo w ogóle) wiemy, jak ten stan zakwalifikować i jak taki stan się nazywa. Ale nawet jeśli wiemy, że to jest strach i pamiętamy to słowo, w tej sytuacji mownej nie chodzi nam o to, żeby to pojęcie nazywać czy omawiać. Nasze działania polegają na demonstracji wyobrażenia emocjonalnego zgodnie z przyjętą konwencją kulturowo-lingwalną. Dlatego też nie wydajemy jakichś nieodtwarzalnych odgłosów, a używamy czegoś na wzór - Oj! Jejku! Jezus! O kurwa!, czyli używamy ekspresywów werbalnych charakterystycznych dla polskiej kultury językowej.

Zatem mamy pełne prawo odnieść takiego typu jednostki do domeny onomazjologii, przy czym raczej do leksykologii niż do składni bez względu na to, że trudno je nazywać nominatami sensu scricto, a procedura ich powstawania nieco różni się od klasycznej nominacji. Zresztą pojęcie onomazjologii już dawno zostało poszerzone o precedensowe jednostki predykatywne i półpredykatywne (paremie, sentencje, frazemy predykatywne, porównania, frazeoschematy, teksty i wypowiedzi precedensowe) (zob.: C. Лещак, О. Лещак 2005; С. Лещак 2008; О. Лещак 2018). Dlatego też samo określenie onomazjologii jako teorii nominacji dawno powinno zostać zrewidowane. Jest to dyscyplina językoznawcza, która bada akty werbalizacji od strony relacji 
pomiędzy treściami intencjąlnymi, zasobem językowym a czynnościami mownymi. Powinna zatem interesować się nie tylko aktami nominacji czy predykacji, ale również ekspresją werbalną.

Badacze wielokrotnie zajmowali się kwestią ekspresji językowej z różnych punktów widzenia oraz z różnym stopniem konkretyzacji danego terminu. Warto zastanowić się nad zróżnicowaniem ekspresji semiotycznej, ekspresji wypowiedzeniowej (mownej) oraz ekspresji leksykalno-semantycznej. Są to trzy różne pojęcia, które często są ze sobą mylone. O ekspresji semiotycznej mówimy wtedy, jak przeciwstawiamy pragmatykę zachowania semiotycznego, czyli odróżniamy próby wypowiedzenia się, wyrażenia przez mówcę intencji i zamiarów od prób wywarcia wpływu na rozmówcę, adresatów, wymuszenia na nim czy nich jakichś czynności lub zachowań. Nie o ten typ ekspresji nam chodzi, gdyż ekspresywy werbalne, o których tutaj mowa, mogą służyć obu celom - zarówno wyrażeniu swego stanu emocjonalnego czy wyobrażenia zmysłowego, jak i aktu wolitywnego, wywierającego wpływ na adresata.

Jeśli chodzi o ekspresję jako formalno-motorycznej charakterystyce aktu mowy, to to także nie jest nasz obiekt badania. $Z$ reguły ekspresywy werbalne wypowiadane są z pewnym naciskiem intonacyjnym i napięciem fonetycznym, lecz nie jest to reguła. Niektóre przejawy emocjonalnowolitywne mogą być mało ekspresywne w tym znaczeniu terminu. Poza tym treści emocjonalne lub wolitywne mogą być wyrażane również poprzez różnego rodzaju środki konotacyjne - zarówno na poziomie derywacji, jak też składni. Na konieczność zróżnicowania nominacji i ekspresji stanów psychicznych lingwiści zwracają uwagę dość dawno, lecz nie zawsze wyraźnie oddzielają ekspresji jako zabiegu werbalizacyjnego polegającego na wyrażaniu treści niepojęciowych za pomocą znaków leksykalnych a ekspresji jako modalnego ukształtowania słów lub zdań. A. Kiklewicz, omawiając pojęcie funkcji ekspresywnej u K. Buhlera, pisze: „Należy szczególnie zwrócić uwagę na różnicę między nominacją stanów psychicznych człowieka jako realizację funkcji nominatywnej a nacechowaniem intensjonalnym wypowiedzi lub tekstu" (Kiklewicz 2010: 20). Niestety, przedstawiona opozycja w sensie konceptualnym nie jest zbyt fortunna, ponieważ przeciwstawia się realizacja funkcji nominatywnej, jako procedura nazywania treści pojęciowych oraz „nacechowanie intencjonalne", czyli konotacja wypowiedzi lub tekstu. Można się domyślić, że w drugim przypadku nie chodzi o ekspresję za pomocą znaków, lecz o zabarwienie ekspresywne wypowiedzi poprzez wykorzystanie środków gramatycznych i prozodycznych podczas tworzenia wypowiedzi jako znaku predykatywnego. Ten typ ekspresji można nazwać formalno-gramatycznym lub wypowiedzeniowym. Nas zaś interesuje przede wszystkim ekspresja.

Nas interesuje trzeci typ ekspresywności, mianowicie wyrażenie pewnych stanów i wyobrażeń, które nie występują w postaci pojęcia i są nie nazywane czy deliberowane, lecz wyłącznie demonstrowane niemalże bezpośrednio. Słowo niemal jest tutaj bardzo istotne. Jak już mówiliśmy wcześniej, nie interesują nas całkowicie bezpośrednie akty przejawu stanu fizjologiczno-psychicznego, nawet gdy ich tworami są jednostki „słowopodobne”. Żeby się stać 
jednostką języka taki twór powinien zostać semiotyzowany podwójnie: a) w sposób psycholingwalny (stać się zapamiętanym i odtwarzalnym przynajmniej przez jego twórcę) i b) socjolingwalny (stać się rozpoznawalnymi i interpretowalnymi przez przynajmniej jednego odbiorcę). Zatem zapowiedziana demonstracja nie może być zupełnie jednostkowym aktem przejawu jednostkowego stanu psychicznego. Bezpośredniość takiej werbalizacji jest dość umowna. Owszem, trudno nie zauważyć różnicy między wykrzyknieniem ej lub aj będącymi ekspresją odpowiednio zawołania i bólu, a czasownikami ejkać lub ajkać, które są nazwami werbalnych czynności wywołanych chęcią zawołać kogoś czy wyrazić ból. Wykrzykniki są o wiele bliższe bezpośrednim stanom psychicznym niż czasowniki. Jeszcze bardziej abstrahowane i oddalone od bezpośrednich aktów woli lub reakcji emocjonalno-fizjologicznych są nominatywne określenia zawołać (kogoś) lub zakrzyczeć z bólu, natomiast rzeczowniki zawołanie lub krzyk bólu są jeszcze bardziej abstrakcyjne. Jednakże problem polega na tym, że wykrzykniki, pomimo ich bliskości do aktualnych stanów psychicznych, nie mogą być uznane za bezpośredni przejaw tych ostatnich dlatego że stany takie są, z jednej strony, zawsze unikatowe i zupełnie subiektywne, a z drugiej niemal zawsze pozakulturowe i pozaetniczne. Wykrzykniki jako znaki ekspresji werbalnej, w odróżnieniu od paralingwistycznych znaków akustyczno-artykulacyjnych (do których odnieślibyśmy odgłosy naturalistyczne i gesty dźwiękowe ${ }^{13}$ ) oraz dewiacji lingwalnych (np. echolalii), są funkcjami stricte językowymi. Ekspresywy werbalne zawsze są znakami pewnego języka etnicznego, co więcej - są elementami jego zasobu leksykalnego i mogą pełnić funkcje syntaktyczne $\mathrm{w}$ wypowiedziach $\mathrm{w}$ tym języku zgodnie $\mathrm{z}$ jego regułami. $\mathrm{Z}$ pochodzenia mogą one być również pochodnymi nominatywnych i predykatywnych znaków (np. słów pełnoznacznych lub wypowiedzi), jak i ekspresywów niekomunikatywnych (np. niektóre wykrzyknienia jednosylabowe na początku mogły być po prostu odgłosami niewerbalnymi - gestami dźwiękowymi).

Językowe wykładniki wyrażania uczuć czy wrażeń zmysłowych w stosunku do procedur wyrażania sądów lub pojęć pełnią raczej rolę podrzędną, tym bardziej, że o wyobrażeniach rzadko mówimy wprost (Szumska 2000: 199). Jeśli to czynimy, to faktycznie wyrażamy coś, co nie jest wyrażalne w sensie logicznym, bo należy do sfery niepojęciowej. Czym innym jest samo uczucie czy wrażenie, czym innym wyobrażenia lub pojęcia o nich, a czym innym werbalizacja tych pojęć i wyobrażeń za pomocą słów (Pajdzińska 1990: 87). Zatem w odróżnieniu od nominatywnych znaków językowych, które werbalizują pojęcia czy relacje pojęć, oraz od wypowiedzi jako znaków mowy, które werbalizują sądy propozycyjne, ekspresywy werbalne demonstrują informacje niepojęciowe, a w odróżnieniu od znaków ekspresji niewerbalnej, które mogą bezpośrednio demonstrować aktualne stany psychiczne hic et nunc, ekspresywy werbalne demonstrują przede

13 Jak pisze Rafał Michalski, „dźwiękowe gesty - zawołania (przedjęzykowe wykrzykniki) stanowiące akustyczny analogon cielesnych gestów, posiadają one wartość sytuacyjną (Situationswert) - odsyłają bowiem do całego kompleksu działań, emocji, wrażeń, związanych z wyrażoną przez nie sytuacją. Zawołania te artykułują osadzone w motorycznej pamięci «figury ruchu», które zawierają w sobie wskazówki dotyczące całej sekwencji działań” (Michalski 2015: 83). 
wszystkim uogólnione wyobrażenia o takich stanach i czynią to za pośrednictwem pewnej etnicznej kultury językowej. Dowodem na to, że ekspresywy werbalne nie są bezpośrednimi znakami stanów psychicznych jest dość częste wykorzystanie ich w sytuacjach udawania emocji lub aktów woli lub kontrolowane ich użycie w dyskursie publicznym (kurka wodna, kurczę blade lub kuźwa zamiast kurwa).

Kwestia ekspresji leksykalno-semantycznej jest w lingwistyce dość problemowa. Problem polega, po pierwsze, na tym, że w literaturze naukowej najczęściej tego typu zjawisko sprowadza się wyłącznie do wyrażenia emocji (pomijane są przejawy woli i wyobrażenia zmysłowe). Lingwiści są zgodni co do tego, że ekspresywność znamionuje różnego typu jednostki (elementy) języka (Skubalanka 1972:124), lecz nie zawsze zwracają uwagę na różnorodność oznaczanej przez jednostki ekspresywne informacji. Władysław Lubaś dzieli ekspresję na dwie grupy - pozytywną i negatywną. Do pierwszej grupy zaliczył: atencję, aprobatę, radość, podziw, żart, przychylność, pobłażliwość, wzruszenie, poufałość, współczucie, ubolewanie. W grupie drugiej znalazły się: nostalgia, niedowierzanie, niezadowolenie, zniecierpliwienie, dystans, negacja, lekceważenie, rozczarowanie, zakłopotanie, ironia, tęsknota, smutek, złośliwość, gniew, zazdrość, pogarda, obraza, strach, lęk, żal, rubaszność, grubiaństwo, wulgarność, agresja (Lubaś 2003: 186-203). Przykład ten pokazuje, że ekspresja jest tutaj skojarzona (albo i utożsamiona) albo wyłącznie z emocjami, albo z ich pochodnymi - uczuciami (które z reguły nie są od emocji odróżniane). Przejawy woli (hej, jejże, kici-kici, no, hop-hoop), wyobrażenia o wrażeniach akustycznych (pukpuk, brzdęk, muu, hau-hau, i-ha-ha, kap-kap), optycznych (błysk, mig-mig), kinestetycznych (niuchniuch, mrug, hops-hops-hops, sru, mniam, głask-głask, smyr-smyr, gilu-gil, drap-drap, chlup-chlup) albo mieszanych (pierdut, bams, pstryk) pozostają poza typologią ekspresji. Jeśli jednak zwrócimy się do Encyklopedii językoznawstwa ogólnego, to zauważymy że tam funkcja ekspresji jest rozpatrywana o wiele szerzej. Wiąże się z faktem, że „pewne cechy wypowiedzi odpowiadają na zasadzie związku przyczynowego określonym cechom fizjologicznym i psychicznym mówiącego i tym samym stanowią dla słuchającego sygnały o jego stanie fizjologicznym i psychicznym" (Polański 1999: 190).

Po drugie, sytuacje wyrażania stanów psychicznych za pomocą środków leksykalnych zwyczajowo łączone są w jedną całość z aktami nominacji pojęć o emocjach (do ekspresji emocji załączane są wyrazy smutny, wesoły, radość, szczęście, przygnębienie, tęsknić, płakać etc.) lub z procedurami predykatywnego wyrażenia emocjonalnie zabarwionych sądów (Jest mi smutno; Czut przygnębienie; Skakał z radości), czyli, jak już wcześniej wspominaliśmy, sprowadza się albo do konotacji jednostek leksykalnych, albo do pragmatyki wypowiedzi na poziomie składni zdania. W wypowiedzi Zofii Czapigi na temat ekspresywności wypowiedzeń czytamy: „W każdym języku brak jest wystarczającego leksykonu pozwalającego adekwatnie nazywać złożone stany emocjonalne czy subtelne ich odcienie, stąd konieczne jest wykorzystywanie w tekście całego 
kompleksu środków ich przekazu” (Czapiga 2015:20). Wyraźnie widać, że pojęcie ekspresji tutaj wiąże się, z jednej strony, tylko ze „złożonymi stanami emocjonalnymi” (o czym już mówiliśmy wyżej), a z drugiej, z „nazywaniem” takich stanów. Naszym zdaniem, ani nazywanie emocji (a także aktów woli czy wrażeń), ani ich opis czy też omawianie syntaktyczne nie jest tożsame z ekspresją leksykalno-semantyczną. Chodzi nam o sytuacje, gdy emocje, przejawy woli i wrażenia zmysłowe są demonstrowane $\mathrm{w}$ formie językowej. Jest to jakościowo inna procedura niż nazywanie (nominacja) czy omawianie (predykacja).

Należy zauważyć, że leksyka i gramatyka w znacznie mniejszym stopniu zdolne są do realizacji bezpośredniej ekspresji informacji niepojęciowej niż formalne środki mowy ustnej (mamy na myśli przede wszystkim fonetykę i prozodię). Przytłaczająca większość znaków językowych oznacza pojęcia (wystarczy wspomnieć większość prac z semiotyki, w których tradycyjnie oznaczane znaku jest utożsamiane $\mathrm{z}$ pojęciem) lub relacje pojęć (tutaj przodują środki gramatyczne). Jednakże przekaż wyłącznie leksykalno-gramatyczny nie posiada możliwości pozawerbalnych środków ekspresji uczuciowej (mimiki, gestów, intonacji, siły i tembru głosu). Dlatego też zarówno językoznawca czy zwykły odbiorca, który ma przed sobą tylko tekst pisany, nie odtwarza samych emocji, lecz głównie pojęcia o nich zawarte w znakach językowych i regułach składniowych (Grabias 1994: 254-257), zresztą jak i nadawca tekstu pisanego nie ma możliwości bezpośredniego wyrażenia stanu psychicznego. Nie ratują pod tym względem i takie innowacje sieciowe, jak emotikony. W mowie ustnej takie możliwości pojawiają się dzięki wspomnianym środkom niewerbalnym. Pewnego rodzaju kompromisem pomiędzy werbalizacją pojęciową (nominacją i predykacją) a ekspresją paralinwistyczną zarówno w mowie ustnej, jak i pisanej stają się będące obiektem naszej uwagi ekspresywy werbalne. Pod względem semantycznym zajmują one pośrednią pozycję w porównaniu do nacechowanych (konotacyjnych) znaków nominatywnych (słów, frazemów, frazeologizmów, wypowiedzi precedensowych) oraz tzw. „ekspresywów niekomunikacyjnych”. Jak zauważył A. Kiklewicz, „W przypadku ekspresywów niekomunikacyjnych emocje są nie tyle wyrażane, co bezpośrednio przeżywane w akcie mowy, co znajduje swój wyraz w różnego rodzaju odstępstwach od reguł języka, na przykład związków gramatycznych lub szyku wyrazów, a także w specjalnych, emotywnie nacechowanych wzorcach syntaktycznych" (Kiklewicz 2009: 92). Do ww. ekspresywów niekomunikacyjnych jako niewerbalnych znaków symptomatycznych (A. Kiklewicz) odnieślibyśmy również różnego rodzaju niejęzykowe przejawy intonacyjne wraz $z$ hezytacjami i całym wachlarzem znaków paralingwistycznych o charakterze ekspresywnym, które „funkcjonują na mocy naturalnego związku między emocją człowieka i charakterem jego zachowań” (tamże).

Kiklewicz wprowadza dość interesujące pojęcie tzw. „ekspresywów egocentrycznych” wykorzystywanych w sytuacjach wyrażania stanów psychicznych (w domyśle - nie posiadających statusu pojęć czy sądów): „istnieją sytuacje niekomunikacyjnego użycia języka - tzw. zachowania 
egocentryczne (..), kiedy na pierwszy plan wysuwają się treści ekspresywno-emotywne" (Kiklewicz 2010: 14). Do takich jednostek badacz zalicza nie tylko większość wykrzykników, ale również motoryczne akty niekontrolowane - echolalię (tamże). Z naszego punktu widzenia echolalie są raczej symptomami, czyli rodzajem znaków naturalnych (na równi z oznakami czy śladami) i nie są funkcjami językowymi. Dlatego nie da się utożsamić ww. ekspresywów egocentrycznych w koncepcji Kiklewicza z naszymi ekspresywami werbalnymi. Poza tym nie do końca jasne, dlaczego prof. Kiklewicz wyprowadza stany psychiczne o charakterze wolitywnym czy mieszanym (kognitywno-emocjonalnym, kognitywno-wolitywnym i pod.) poza granice ekspresywów egocentrycznych, pisząc „Na marginesie należy zaznaczyć, że funkcja wykrzykników nie sprowadza się do realizacji egocentrycznych aktów mowy - na przykład polski wykrzyknik $e$ ! może wyrażać zniecierpliwienie, zniechęcenie, lekceważenie, jak również zdziwienie połączone z uznaniem" (Kiklewicz 2009: 91). Naszym zdaniem, akty woli są dokładnie takimi samymi podmiotowymi ("egocentrycznymi") funkcjami informacyjnymi, jak stany emocjonalne, zatem nie widzimy przeszkód, żeby zaliczać je do egocentrycznych aktów ekspresji mownej. Jednostki leksykalne, które określamy mianem ekspresywów werbalnych, są demonstracjami zarówno ogólnych (kulturowo-językowych) wyobrażeń o emocjach, jak też ogólnych wyobrażeń o aktach woli i stanach wolitywnych.

Chciałoby się jednak zwrócić uwagę na to, że niepojęciowe stany psychiczne nie sprowadzają się wyłącznie do przejawów woli czy emocji. W świadomości każdego człowieka występują również liczne wyobrażenia sensoryczne - akustyczne, optyczne, taktylne, kinestetyczne, smakowe i zapachowe. Werbalne ekspresywy zmysłowe zasadniczo nie różnią się od wolitywnych i emocjonalnych. Przede wszystkim tutaj warto wymienić onomatopeję. Są to ludzkie wyobrażenia o dźwiękach wydawanych przez zwierzęta lub przedmioty nieożywione. A. Madeja uważa, że onomatopeiczne wyrazy nie odnoszą się do ekspresywów: „Podstawową różnicą między onomatopejami a wykrzyknikami ekspresywnymi może być to, że pierwsze nastawione są na naśladowanie rzeczywistości zewnętrznej, gdy tymczasem wykrzykniki ekspresywne naśladują naszą ludzką, wewnętrzną rzeczywistość. Wykrzykniki pełnią przede wszystkim funkcję ekspresywną natomiast onomatopeje to środki porozumienia nastawione na odbiorcę" (Madeja 2012: 223). Naszym zdaniem, to zróżnicowanie jest ważne wyłącznie na poziomie typologizacji ekspresywów ze względu ich podmiotowości (egocentryczności) czy przedmiotowości (intencjonalności). O wiele ważniejszym nam się wydaje to, że ani ups!, ani aj!, ani bam, puk czy bzz nie są znakami pojęć, lecz wyrażają stany psychiczne człowieka. Demonstracja opisowa pewnego dźwięku jest taką samą demonstracją, jak demonstracja emocji czy przejawu woli. Poza tym klasyczne onomatopeje typu muu, czy chat chat, bzzzz, dzyń dzyń wcale nie są bardziej , nastawione na odbiorcę" niż ups, aj oh, wow. o?! Słusznie zresztą zauważa prof. A. Kiklewicz: „Granica między zachowaniami komunikacyjnymi i niekomunikacyjnymi nie zawsze jest wyraźna, 
w każdym razie możliwe są sytuacje, w których egocentryczne zachowania językowe mogą być potraktowane jako intencjonalne, skierowane na adresata" (Kiklewicz 2009: 93).

Ekspresywy onomatopeiczne jako znaki językowe posiadają identyczne cechy semiotyczne i składniowe, jak inne ekspresywy werbalne. Mogą zarówno zastępować wypowiedzenia niezależnie od kontekstu werbalnego (czyli występować w roli wypowiedzi nierozczłonkowanej, niepropozycjonalnej), lub być integralną częścią wypowiedzi propozycjonalnych (najczęściej jako orzeczenie). Do tejże grupy można także odnieść wyobrażenia optyczne i kinetyczne, czyli wyobrażenia o czynach, które można uważać za jednostki przejściowe pomiędzy klasycznymi ekspresywami werbalnymi a czasownikami jako nominatami czynności i stanów. Chodzi o wyrażenia na wzór - błysk, mig-mig, skok, bach, niuch-niuch, mrug, hops-hops-hops, pierdyk. Można je nazwać kinetywami albo ekspresywami predykatywnymi. Nie są to ani nominaty pojęć (jak, np. rzeczowniki blysk, skok, huk, uderzenie, mignięcie, czy czasowniki powąchać, mrugnać, skakać, spaść), ani predykacje sądów (Latarnia błysnęła, Chłopak skoczyt, Ksiązka spadła z hukiem), chociaż w odróżnieniu od innych ekspresywów werbalnych o wiele częściej jednostki tego typu mogą występować w roli orzeczeń, niż być samodzielnymi wypowiedziami niepropozycjonalnymi: Nie wiem czy we wtorek nie będę musiała zrobić krok do przodu i pierdyk $w$ przepaść; Surowe wrzucam na wrzaca zalewe i one się tak w tym kwasie obracaja, lekko się gotuja, tak tylko mrug, mrug; Co tak jebło gdzieś na Bałutach: jeb, błysk i koniec: Za chwile będzie niam, niam (wszystkie przykłady z sieci Internet). Są to jednostki językowego zasobu leksykalnego, które służą do zademonstrowania pewnych czynności postrzeganych zmysłami. Mają głównie charakter mimetyczny (jest to artykulacyjna demonstracja wrażeń od pewnego dynamicznego zjawiska). Dlatego tego rodzaju znaki również zaliczamy do ekspresywów werbalnych.

Ale na tym potencjał semantyczny ekspresywów werbalnych się nie kończy. W tej grupie znaków leksykalnych są również dość specyficzne i nieco odbiegające od klasycznej ekspresji (jako wyrażenia intencji) znaki performatywne, czyli czyny werbalne o charakterze intencjonalnym, tj. wycelowane w adresata. Chodzi np. o przywoływania zwierząt stylizowane na odgłosy zwierzęce, które są werbalną demonstracją jednocześnie wolitywnego aktu zachęcenia oraz wyobrażenia akustycznego. Nie jest to ani wynik nominacji (np. rzeczownik przywotywanie czy czasownik przywoływać), ani predykacji (jak np. Chodź do mnie), gdyż jednostki te ani nie nazywają tego aktu woli i tych wyobrażeń akustycznych, ani nie opowiadają o intencjach mówcy, tylko demonstrują jego złożony niepojęciowy stan psychiczny. Poza przywoływaniami zwierząt do tejże grupy można odnieść różnego rodzaju ekspresywy preskryptywne (no-no, hop-hoop, hej, puk-puk, mig-mig, titiit).

Wykrzykniki jako ekspresywy werbalne są podstawową formą werbalizacji w trybie demonstracyjnym treści niepojęciowych: wyobrażeń o stanach emocjonalnych, aktach woli i wrażeniach zmysłowych. Tym się różnią zarówno od znaków nominatywnych, jak 
predykatywnych. Są wynikiem werbalizacji złożonych procesów umysłowych, które składają się na treść życia emocjonalnego danej osoby. Podstawy typologizacji ekspresywów werbalnych mogą być różne. Ze względu na charakter relacji między znakiem a oznaczanym wszystkie ekspresywy werbalne można w ślady Elżbiety Orwińskiej-Ruziczki (1992) podzielić na:

a) impulsywne, demonstrujące stany psychiczne (emocjonalne i wolitywne) podmiotu;

b) preskryptywne, demonstrujące wolitywny wpływ podmiotu na adresata (OrwińskaRuziczka nazywa je imperatywnymi);

c) mimetyczne, demonstrujące wrażenia sensoryczne od działań zewnętrznych względem mówcy wraz z quasi-imitacją tych działań (u Orwińskiej-Ruziczki użyto terminu reprezentatywne).

Problem powstawania i funkcjonowania ekspresywów werbalnych wymaga dalszych, bardziej głębokich badań lingwosemiotycznych, zwłaszcza onomazjologicznych.

\section{LITERATURA}

Antas, J., Majewska, M. (2016), W poszukiwaniu jednostki mowy. Metodologiczne refleksje w obliczu nowego rozumienia języka, Pótrocznik Językoznawczy Tertium 1 (1\&2), 3-21.

Czapiga, Z. (2015), O ekspresywności wypowiedzeń emotywnych (na materiale języka rosyjskiego i polskiego). Acta Universitatis Lodziensis Folia Linguistica Rossica. 11, 19-27.

Dokulil, M. (1979), Teoria derywacji. Wrocław.

Kiklewicz, A. (2009), Akty mowy: klasyfikacja dychotomiczna. Media. Kultura. Komunikacja społeczna. $\mathrm{Nr}$ 5, Olsztyn. 87-110.

Kiklewicz, A. (2010), Tęcza nad potokiem... Kategorie lingwistyki komunikacyjnej, socjolingwistyki i hermeneutyki lingwistycznej w ujęciu systemowym. Łask.

Leszczak, O. (2002), Metodologiczne zasady wartościowania i wartość jako koncept metodologiczny. W: Dialog. Komparatystyka. Literatura. Warszawa. 33-65.

Lubaś, W. (2003), Polskie gadanie. Podstawowe cechy i funkcje potocznej odmiany polszczyzny. Opole.

Madeja, A. (2012), Sapie, dyszy i dmucha. Postscriptum Polonistyczne. Katowice. Nr (2)10. 219-230.

Michalski, R. (2015), Geneza języka w perspektywie antropologicznej - stanowiska Arnolda Gehlena i George'a Herberta Meada. W: Filozofia i nauka. Studia filozoficzne i interdyscyplinarne. T. 3. 77-94.

Orwińska-Ruziczka, E. (1992), Funkcje językowe interiekcji w świetle materiału słowackiego i polskiego. Kraków.

Pajdzińska A.,(1990), Jak mówimy o uczuciach?: poprzez analizę frazeologizmów do językowego obrazu świata. W: Językowy obraz świata, pod red. J. Bartmińskiego. Lublin. 87-107.

Polański, K. (1999), Funkcje języka (mowy). W: Encyklopedia językoznawstwa ogólnego, pod red. K. Polańskiego, Wrocław - Warszawa - Kraków. 190.

Rejter, A. (2009), Zewnętrznojęzykowe uwarunkowania przeobrażeń kategorii semantyczno-kulturowych ekspresywnych apelatywnych nazw osób w polszczyźnie. W: Cichońska, M. (red.), Kategorie w języku: język w kategoriach. Katowice. 236-245.

Rogala, A. (2019), Niesemantyczne operatory emocji. Prace językoznawcze. 21/4. 195-210.

Skubalanka, T. (1995), O ekspresywności języka. Annales Universitatis Mariae Curie-Skłodowska. Sectio F, Nauki Filozoficzne i Humanistyczne. 27. 123-135.

Szumska, D. (2000), O emocjach bez emocji. W: Uczucia w języku i w tekście. Wrocław. 199-208.

Лещак, О. (2000), К проблеме понятия функции в функционально-прагматической методологии. W: Rozważania metodologiczne. Język - Literatura - Teatr. Warszawa. 243-254 [Leshchak, O. (2000) K probleme ponyatiya funktsii $\mathrm{v}$ funktsionalno-pragmaticheskoy metodologii. $\mathrm{W}$ : Rozważania metodologiczne. Język - Literatura - Teatr. Warszawa. 243-254].

Лещак, О. (2018), Методологические основания и истоки российской ономасиологии: проблема соотношения номинации и предикации. Studia Methodologica. Nr 46. 7-21 [Leszczak, O. (2018) Metodologicheskiye osnowaniya i istoki rossiyskoy onomasiologii: problema sootnosheniya nominatsii i predikatsii. Studia Methodologica. Nr 46. 7-21]. 
Лещак, С., Лещак, О. (2005), Ономасиологический анализ сверхсловных неидиоматических знаков в современном русском языке. Studia Rusycystyczne Akademii Świętokrzyskiej. Kielce. T. 14. 151-167 [Leszczak, S., Leszczak, O. (2005), Onomasiologicheskiy analiz sverkhslovnikh neidiomaticheskikh znakov v sovremennom russkom yazike. Studia Rusycystyczne Akademii Świętokrzyskiej. Kielce. T. 14. 151-167].

Лещак, С. (2007), Языковое клише. Прагматика, семантика и структура аналитических номинативных неидиоматических знаков в современном русском языке. Kielce [Leszczak, S. (2007), Yazikovoye klishe. Pragmatika, semantika i strukura analiticheskikh neidiomaticheskikh znakov v sovremennom russkom yazike. Kielce]. 